\title{
Old Nordic and Christian Elements in Saami Ideas about the Realm of the Dead
}

\author{
Some Reflections from the Source Material and \\ Previous Research in Saami Religion
}

By Olof Pettersson $\dagger$

In his book The Lapps Professor Björn Collinder writes: "The Scandinavian loan-words in Lappish give striking evidence of the lively intercourse between Lapps and Scandinavians (up to the seventeenth century perhaps chiefly Norwegians). There are about three thousand such loan-words, and at least two hundred (probably many more) of them date from the epoch of Primitive Scandinavia or still earlier times; that is to say, they are at least about thirteen hundred years old. They belong to the same language as Scandinavian runic inscription from the time A.D. 700. [...] This is enough to refute the opinion that the Lapps are savages who have lived in isolation for many centuries. On the contrary, as long as thirteen centuries ago the Lapps, or at least part of them, had learned much from their more advanced neighbors [...]" (Collinder 1949, $37 \mathrm{ff} ., 40$ ) About twenty years later Asbjörn Nesheim makes the claim in his study Eastern and Western Elements in Lapp Culture: "As far back in time as we can trace the Lapps, they have lived in areas where eastern and western elements of culture have met. This fact has left a distinct stamp on every aspect of Lapp culture, and on the language which contains a great number of loanwords" (Nesheim 1967, 104).

Collinder and Nesheim then-amongst several other scholars-have clearly fixed the starting-point which any student in the field of Saami religion must be aware of: Saami culture did not originate and develop in a vacuum. This does not mean however that Saami culture and religion are not something sui generis. To a certain point, the discussion is fairly unanimous: this or that loan word in Lappish comes from Scandinavia. But then the problems amass. The fact that a word or concept has been borrowed from outside does not mean that the original content, the original ideas which the loan word in question expresses, have also been adopted. 
And this is by no means the case when it is a question of abstract words and notions. A word, an idea, a custom is taken over but filled with new content; in its new context it acquires a genuinely Saami conceptual load, which has its original domiciliary rights in Saami, north Eurasian culture. This means in turn that a holistic point of view must be adopted in an analysis of Saami beliefs. Different traditions-or beliefs-have been added to the mother tradition already extant in the Finno-Ugric, North Eurasian context.

The present brief notes on the Nordic and Christian influence on Saami ideas about the realm of the dead proceed from the Saami religion as a whole, examining and explaining it from an external perspective: what connecting-points are there in the "original" mother tradition for the new ideas which have been adopted over the course of time and which have been grafted on to the old? The Saami religion must not be detached from the Finno-Ugric North Euroasian context to which it belongs. A study of the foreign elements in Saami religion can never lead to greater or lesser degrees of probability. This is due primarily to inadequate source material. The sources for Saami religion which we possess are not primary sources, which go back to the Lapps themselves; they have been assembled by outsiders. In other words, they are about the Lapps and are from the 17th and 18th centuries at the earliest. They are in fact, as Louise Bäckman suggests: ' $[\ldots .$.$] ethnographic records of a general kind, where information$ about the religion of the Lapps only takes up an insignificant part of the individual manuscripts" (Bäckman 1975, 50). Those who compiled these records were "children of their time" and bound by the conceptual models of the day and by the frames of reference of their religion-Christianity. These chroniclers-priests and missionaries-were limited in their knowledge of religions other than Christianity to a certain familiarity with classical antiquity and the old Norse sagas of the gods-of which all except of course Christianity were the "work of the devil"- -a knowledge they had possibly acquired during their training. The Saami religion was automatically relegated to the "sphere of the devil". It was to be replaced by Christianity through missionary activity. ${ }^{1}$ It is not surprising therefore that these early writers sometimes made connections between Saami religion on the one hand and Nordic or classical religion on the other, when they were discussing gods whose character and activities reminded them of classical or old Norse divinities. The available source material on Saami religion reveals a number of names for the place or places to which the dead go, together with ideas about life after the present one. That these Saami ideas

\footnotetext{
${ }^{1}$ For an evaluation of the source material see Mebius 1968, $9 \mathrm{ff}$; Bäckman 1975, $50 \mathrm{ff}$.
} 
show elements from non-Saami religion and culture cannot be questioned and has been pointed out with greater or lesser emphasis by a number of scholars who have occupied themselves with Saami religion. ${ }^{2}$ The present reflexions about the Nordic and Christian elements in Saami ideas about the realm of the dead make no claim at all to represent any kind of comprehensive analysis, but merely attempt to introduce certain fundamental viewpoints concerning Saami religion beginning from the sources and from previous research. In this context, the problem of confrontation between different religions will also be considered in more general terms.

The first and fundamental starting-point for the study of the meeting of the Saami religion with the old Nordic and Christian ones will be the Saami religion itself in its Finno-Ugric and North Euroasian context and not the old Norse or Christian beliefs.

The question is then: to what extent can it be demonstrated that this religion has undergone influence from old Nordic and Christian elements? Earlier research-from the turn of the century-on Nordic and Christian influences on Saami ideas about the realm of the dead has sometimes reversed the question and asked about the Saami elements in Saami ideas about the realm of the dead; the essential contents of these ideas were supposed to be of Nordic or Christian origin. Thus Axel Olrik, for example, believed that Saami ideas about the realm of the dead were based on the Hel concept of the Nordic peoples (Olrik 1905, 36-64). ${ }^{3}$ Helge Rosén worked in the same way: the Saami ideas about the realm of the dead had been shaped from concepts which had been borrowed from neighbouring Teutons during the Middle Ages (Rosén 1919, 16). Fritzner points out how the Norwegian Lapps had contact with Christianity even before the reformation (Fritzner 1877, $135 \mathrm{ff}$.). According to him, there were still elements of Catholic ritual to be found among the Lapps at the end of the 19th century. As an example of this Fritzner cites the detail that Saturday was

\footnotetext{
${ }^{2}$ Only a few studies can be mentioned here as examples of research into this particular problem in Saami religion: Fritzner 1877; Bäckman 1975; Krohn 1906 (Krohn believes that Saami mythology is largerly taken from Norse religion and that it thus "bietet uns nicht nur ergiebige quellen (!) und verlässliche zeugen (!) zur germanische mythologie (!) sondern auch ein sicheres kriterium (!) zur beurteilung (!) der religiösen vorstellungen (!) in den Eddaliteratur und zvar zur unterscheidung (!) des skandinavischen gemeingutes (!) und des speciell isländisch erwerbes (!), des echten erbteiles (!) aus dem heidentum (!) und des christlichen lehngutes (!) darin' Krohn 1906, 180); Olrik 1905; Pettersson 1957; Rosén 1919; Unwerth 1911; Wiklund 1916; Mebius 1968; Hultkrantz 1962.

${ }^{3}$ One of the great authorities in the area of old Germanic religion, J. de Vries, values Olrik's research highly and believes that his studies have shown "die grosse Bedeutung die die Glaubensvorstellungen der Lappen für die Forschung der germanischen Heidentums haben, wie sie ihre rituelle Handlungen teilweise von ihren südlichen Nachbarn übernommen haben und zwar in einer sehr frühen Periode" (Vries 1956, 63).
} 
dedicated to the Virgin Mary (Fritzner 1877, 41; Leem 1767, 493). Differentiation in the realm of the dead is according to him the result of the meeting with the Christian population (Fritzner 1877, 253). Von Unwerth (Unwerth 1911, $5 \mathrm{ff}$., $10 \mathrm{ff}$.) goes very far in his emphasis of the old Nordic influence, claiming amongst other things that the god of death Rotu (Rota) is identical with Odin. We shall return to this shortly.

Von Unwerth also claims that the Lapps have taken the idea that the dead lived in certain holy mountains from the Teutons: "Hier herrscht völlig die Vorstellung: jede Familie hat ihren Opferberg, mit strengen Bestimmungen ist seine Heiligkeit festgelegt, man glaubt dass die Verstorbenen in den Berg eingehen und drinnen ein dem menschlichen völlig gleiches Leben führen ganz wie die álfar des nordischen Volksglaubens, Lebende werden mit unter zu ihnen eingelassen wie die Isländer Thordr in den Totenberg seines Geschlechtes [...]" (Unwerth 1911, 30). More recently, in 1969, Nordland introduced the same viewpoints (Nordland 1969, 73). Starting from the Eyrabyggiasaga, where there is a description of how the fanatical Aesir worshipper, Torolv Mostraskjegg, obtained his own death mountain, Helgafjell, Nordland attempts to show that the same idea was present in the beliefs of the Lapps. Some twenty years earlier, Nils Lid had tried to show that the holy mountain, like the realm of the dead, had come from the Teutons (Lid 1942, 144). Uno Harva (Harva 1915, 22) and Arbman (Arbman 1960,127) assume that the Saami mountain of death has a Germanic model. Åke Hultkrantz may be said to sum up the view of modest scholarship when he writes: "Nach allem zu urteilen ist die Idee vom Saivoheim (saiviaimo) als jenseitigem Wohnsitz für bestimmte Verstorbene unter skandinavischer Vermittlung aufgenommen" (Hultkrantz 1962, 294).

The above scholars are all agreed that we are dealing with a Nordic loan as far as Saami ideas about the holy mountains are concerned. Naturally, as Louise Bäckman has pointed out (Bäckman 1975, 90f.), it is not unreasonable to suggest that these ideas could be Saami in origin. Similar ideas -mountains as an abode for the dead-are mentioned in Russian sources. One Russian source, referring to the period around the eleventh century mentions populated mountains among the Jugrers:

"(1096) And I will relate what a person from Novgorod [...] before this last year told me: He had sent his servant [...] to Petschorerne-for these people pay tax to Novgorod-and after my servant had arrived among them, he went from there to the Jugrers. But the Jugrers are a silent, heathen people (of a foreign tribe) and border with the Samoyeds in the northern regions: these (Jugrers) said to my servant: we find a mysterious miracle, which we have not heard (mentioned) before now; and it is now three years since this miracle first began. There are mountains, on the way 
to Lukomorie, and they reach almost to the sky and in these mountains there is a great roaring and talking, and they split open the mountain if they wish to break it. And if someone gives them iron, or a knife, or a broad-axe, then they give animal hides in return [...] And there is also a road to these mountains, which is impassable, because of the many precipices, deep snow and forest, and therefore always inacessible" (Akiander 1848, 23). Wiklund has some information about the belief in holy mountains occurring in Russia, but there are no dead people in them (Wiklund 1916, 47, note 1). According to the data in the Russian source referred to, the idea of mountains of the dead is found not only in Scandinavia but also in the eastern parts of the North European area (Craigie 1920, $851 \mathrm{ff}$. .). $^{4}$

In spite of this information, there is much to suggest that we are dealing with a Nordic influence, even if-bearing in mind the part played by mountains and fells in the Lapland landscape-and the fact that the concept is found outside Scandinavia-it is tempting to think that it could be a purely Saami, North Eurasian idea. But bearing in mind the geographical proximity and the clear Nordic parallels, it is reasonable to rest with the assumption that ideas about the saijvo mountains are of Nordic origin.

It is by no means clear, however, that the Lapps also adopted the old Nordic ideas which were associated with these Nordic mountains of the dead in their Nordic context. Saijvoaimo is no realm of the dead, but rather-as Louise Bäckman has clearly shown- "[...] a permanent residence for deities [...] i.e. guardian spirits, tutelary geniuses, and at a later stage in the history of the Southern Lapps, subterranean ones" (Bäckman $1975,100 \mathrm{ff}.)^{5}$

"Shamanistic ideology includes a feature according to which the souls of shamans or worthy persons become, after their death, guardian spirits for those still living, thus acquiring a status different to that of ordinary mortals in the 'other life' [...]'' (Bäckman 1975, 103).

I have previously suggested (Pettersson 1957, $132 \mathrm{ff}$.) that sájvo was a realm of the dead like Jabmeaimo. Through subsequent studies of shamanism and the belief in guardian spirits I have come to a different conclusion to the one I reported in 1957. Sájvo cannot be equated with a realm of the dead in the manner of Jabmeaimo, even if a confusion of the two often appears in the sources, and the boundary is often fluid. Arbman expressed the matter in these terms in a posthumous article from 1960 . He believed

\footnotetext{
${ }^{4}$ According to Craigie 1920 similar ideas are found in the religions of primitive peoples.

5 Arbman 1960, 124: "We may thus confirm-a fact that seems to have been completely forgotten in the lenghty discussion of the saivo mountains-that in large parts of the Scandinavian area according to Saami belief every holy mountain has been populated by a quite small group of divine spirits-a Saami miniature pantheon as it were."
} 
that "these sacred mountains as dwelling places for the souls of departed Lapps cannot really, as people generally seem to have imagined, have been identical with either an as it were idealized or an improved form of the underworld Jabmeaimo. In actual fact, it was a completely different world, which at the time of the Lapps' conversion to Christianity did not have, and had not previously had, anything in common with Jabmeaimo" (Arbman 1960, 124 ff.).

To summarise the Nordic/Christian influence regarding the sájvo ideology, it is highly probable that we are dealing with an old Nordic loan of the concepts of the sacred mountains. The parallels between old Nordic sources on the one hand and Lappish ones on the other are so strong, that one is justified in assuming a Nordic influence. But it is only the external frames which have been borrowed, i.e. the ideas about the sacred mountains. The Lapps have then "filled in" these frames with their own native, religious content, relating it to Saami ideas about the shaman's guardian spirits and other types of spirits. We meet a process here which we may observe in different contexts in the world of religion: in confrontations between religions and cultures there is never a complete and unqualified adoption of an idea from the "alien" religion from which the loan takes place, but the borrowed ideas are filled with or supplemented by the original concepts, i.e. those of the mother tradition. The new becomes a brick which is adapted or fitted into the old system of beliefs. Thus, even if the sájvo probably has its external models in the old Nordic ideas of Helgafjell, the content of the Saami ideas is shaped according to a genuine Saami model, where shaman ideology is of decisive significance. ${ }^{6}$

The real realm of the dead for the Lapps was Jabmeaimo (Jámie-ájmo). ${ }^{7}$ It is genuinely Saami in character and has its equivalents among different Finno-Ugric and North Eurasian peoples (See Pettersson 1957, $137 \mathrm{ff}$.). Ideas about Jabmeaimo are found in the mother tradition. It was situated below the earth and undifferentiated. Many features of Saami and North Eurasian beliefs about the realm of the dead reveal elements at a general level in common with ideas found in many other religions (Hel in the Nordic countries, Hades among the Greeks, "the land without return" among the Babylonians etc.) without for this reason permitting us to form any conclusions about identity or common origins. We only speak of a phenomenological resemblance. The Saami Jabmeaimo is sui generis and must only be interpreted in its own terms, i.e. starting point for interpretation is the Saami realm of the dead and nothing else. As mentioned previously, a

\footnotetext{
${ }^{6}$ I refer to Bäckman \& Hultkrantz 1978 with its comprehensive bibliography.

${ }^{7}$ The sources have different designations: Jabmeaimo, Jamikaimo etc.
} 
number of scholars have attempted to suggest that the Saami ideas of Jabmeaimo have been borrowed from the ancient Teutons.

"A little way into the earth is Jabmiaimo, where Jabmiakka, the mother of death is mistress. All mortals there are as powerful as they have been in the world and they receive a new body, in place of the one that is rotting on earth" (Sidenius 1910, 59). We may let these words of Lennart Sidenius represent what we actually know of ideas about the realm of the dead in the Saami religion:

the realm of the dead is in the earth the realm of the dead has a mistress, Jabmiakka the realm of the dead is undifferentiated.

The realm of the dead is created from the world of the living. There is no idea of any resurrection. Sources going back to T. von Westen (Westen 1910, 3), H. Forbus (Forbus 1910, 35) and others give similar evidence. In contrast to this picture of Jabmeaimo, however, there are certain statements which point towards ideas of differentiation with regard to the realm of the dead. Kildal, writes: "[... .] if the Lapp has not obeyed his gods, then his soul comes to the most evil Rota down in Rotaimo, which lies quite deep in the earth where it also acquires a new body" (Kildal 1910, 89), and Forbus says: "Those who dwell deep down in the earth are in Rotaimo, or place of torment, where those souls remain who have not obeyed their gods here in life" (Forbus 1910, 36). ${ }^{8}$

The source material, which can here only be briefly indicated, is very meagre and difficult to interpret, but suggests the possibility of differentiation, with one realm for the good and another for the bad. Even if the information is vague, the fact remains that the idea of a differentiated realm of the dead appears in the available source material. The question is what has inspired these ideas:

Are they ideas which have emerged from the Saamis' own religion, or are these ideas the result of old Norse/Christian influence? The answer to this question cannot go beyond conjecture. The vagueness and confusion of these ideas result from the fact that it was originally a matter of an undifferentiated realm of the dead: the new ideas about a differentiated realm of the dead are from later and not integrated in the Saami cosmology. This does not, however, eliminate the possibility that concepts of a differentiated realm of the dead were part of a genuine, original Saami concept existing as a vague element in ideas which later developed into more

${ }^{8}$ Cf. Forbus 1910, 37: "Those who have lived wicked lives remain for ever in Rotaimo." 
concrete, if still very vague, ideas about one realm of the dead for the good and another for the bad-those who had not "obeyed their gods".

The Finno-Ugric, North Eurasian material shows similar ideas about places for the evil and the good after death: the Jurak Samoyeds say that the evil go to the evil god, Ngaa, whilst the good go to the good god, Num, the god of heaven. Lehtisalo (Lehtisalo 1924, $133 \mathrm{ff}$.) denies that Christian/ Russian myths could have carried these ideas to the Jurak Samoyeds. He gives an account of various myths and suggests that they are of JurakSamoyed origin. Similar ideas are found among the Voguls, the Ostyaks, the Mordvins etc. ${ }^{9}$

From a phenomenological point of view, I would claim that within most religions we find ideas of right and justice transcending earthly existence. Thieves, murderers etc. are excluded from society here in life. It follows as a logical consequence of such thinking that life after death excludes from society those people who are regarded as anti-social, "evil", here on earth. Such "thoughts of retribution" were present in embryo in the original religion and have served as a point of contact for possible ideas coming from outside. Moreover, the Saami religion is characterised by a high degree of suggestibility (cf. Nilsson 1916, 304), which creates a tendency to adopt other ideas. The combination of embryonic original ideas about retribution and religious suggestibility facilitates and explains this adoption, which is actually a reinforcement of already extant elements. What has been adopted is actually nothing new. The idea, inherent in religion, of a differentiated realm of the dead may have been reinforced from two directions, Christian and old Norse. Even before the Reformation in Scandinavia, the Saamis, as has been suggested, had encountered Christian ideas about purgatory. And there is no doubt that the Saamis not only came into contact with, but also adopted, Christian ideas. These included the doctrine of heaven and hell (cf. Fritzner 1877, $138 \mathrm{ff}$.). The concepts of differentiated realm of the dead which we encounter in Saami religion consist of three components:

original Saami elements

the influence of Christianity through missionaries old Nordic ideas

The Saami element must be linked with the old shamanistic idea of heaven as a region of the universe peopled by gods and spirits. Ideas about life in the realm of the dead as a continuation of life on earth also belong to this Saami component.

${ }^{9}$ For additional examples see Pettersson 1957, $137 \mathrm{ff}$. 
The influence of Christianity is constituted by the Christian belief in life after this one for both the righteous and the wicked, which the missionaries spread and which provides the typically Christian element of their preaching.

The possible old Norse influence with regard to differentiation in the realm of the dead is more difficult to specify. The old Norse Hel was originally undifferentiated. To this concept of Hel, however, there were attached ideas about a paradise for heroes, Valhalla. It is possible that these concepts may have influenced Saami ideas, but the sources are quite silent on this point.

In scholarship it has been almost axiomatic that the Saamis have "borrowed" an essential part of their ideas about the realm of the dead from old Norse beliefs. ${ }^{10}$ The discussion of Norse influence includes the question of whether the underworld god Ruto was of Norse origin. The figure of Ruto is only mentioned in the Norwegian material from the 18th century and to find evidence for this in the source material is impossible. In my study from 1957 Jabmek and Jabmeaimo I have, in association with Holmberg-Harva, tried to maintain Ruto's connection with Finno-Ugric, North Eurasian religion and culture (Pettersson 1957, $138 \mathrm{ff}$.), whilst a subsequent essay is entitled The god Ruto. Some Phenomenological Reflections (Pettersson 1983). Professor Gustav Ränk (Ränk 1981) represents the same line of research.

The attempt to find Ruto's origins in Norse culture, which von Unwerth among others strongly asserts, has no foundation in the source material. Hans Mebius, in his study Värrō has demonstrated the weaknesses of von Unwerth's arguments (Mebius 1968, $110 \mathrm{ff}$.). Scholars who have come to assume a Nordic origin have, to demonstrate this, picked out odd details from the source material, which they have then taken out of context. This kind of scholarly work cannot lead to acceptable results.

A survey of the source material and the history of research confirms that we must probably place Ruto in the Finno-Ugric, North Eurasian religious and cultural pattern. The question then arises of to what extent the figure of Ruto has been influenced by Christian ideas borrowed from the Christian figure of the devil. As mentioned previously, Ruto only occurs in Norwegian source material from the 18th century. The sources have their origin in an early missionary context. We should remember that the Christian missionaries who have given us information about the Saami religion worked with a Christian background and with a Christian terminology. ${ }^{11}$ A consistent feature in all the sources is that the function of Ruto is of a protective

\footnotetext{
${ }^{10}$ See the previously mentioned works of von Unwerth, Olrik, Krohn, Fritzner.

${ }^{11}$ Concerning the sources, see Mebius 1968, $21 \mathrm{ff}$.
} 
nature. Sacrifices to him are sacrifices for protection. The picture of Ruto as a kind of explicit devil figure is probably a result of missionary activity and missionary description in the sources.

With differentiation of the Saami realm of the dead, Rotaimo, the home of Ruto came to signify hell. I have previously mentioned the question of different places of residence for the "evil" and the "good". According to Sidenius "the soul in Iamaimo [...] acquires [...] a new body, and then after a time comes to Radien, if one has lived a worthy life according to the will of the gods [...] But those who have lived badly remain in Rotaimo" (Sidenius 1910, 37). Skanke translates Radien-aimo by "the place of the Holy in God's Heaven" (Skanke 1910, 105). Leem (Leem 1767, 410) explains that Radien takes the dead to him after they have been in the realm of the dead for some time. Those who have disobeyed the gods go to Ruto.

The different names for the realm of the dead are vague and confused in the source material. There is no evidence of clear differentiation in the realm of the dead-only a hint of such a division. I consider it likely that this vague division between the realm of Radien and Rotaimo may be ascribed to the preaching of Christian missionaries. The missionaries started from Christianity when they formed their ideas of Saami religion. It was described and analysed from the perspective of the dominant theological beliefs (cf. Holsten 1932, $126 \mathrm{ff}$., Grönlund 1848).

I should like to summarise the foregoing under four points:

1. The source material is so vague that no certain conclusions may be drawn.

2. As far as old Norse influence is concerned, its relevance is limited to the saivo concept.

3. The sources dealing with the realm of the dead in general contain elements which are of Christian origin. The statements of the missionaries have a Christian bias. In them we meet a Saami belief with Christian colouring.

4. The Saami realm of death, Jabmeaimo, is Saami in character, with certain Christian elements (purgatory, heaven-hell, heavenly god-devil).

\section{Bibliography}

Akiander, M. 1848. Utdrag ur ryska annaler. Suomi.

Arbman, E. 1960. Underjord och heliga fjäll i de skandinaviska lapparnas tro. Arv 16.

Bäckman, L. 1975. Sáiva. (Stockholm Studies in Comparative Religion 13.) Stockholm.

Bäckman, L. \& Hultkrantz, A. 1978. Studies in Lapp shamanism. (Stockholm Studies in Comparative Religion 16.) Stockholm. 
Craigie, W. A. 1920. State of the dead (Teutonic). Encyclopaedia of religion and ethics 11. Edinburgh.

Collinder, B. 1949. The Lapps. New York.

Forbus, H. 1910. Prosten Henric Forbus' skrifvelse till K. M:t den 29 mars 1727 med berättelse om den norska lappmissionen och lapparnas hedendom. Källskrifter till lapparnas mytologi. [Ed. by] E. Reuterskiöld (Bidrag till vår odlings häfder 10.) Stockholm.

Fritzner, J. 1877. Lappernes Hedenskab og Trolddomskunst sammenholdt med andre Folks, isaer Nordmaendenes, Tro og Overtro. Historisk Tidsskrift utg. af d. Norske Hist. Foren. 4.

Graan, O. 1899. Relation, Eller en Fulkomblig Beskrifning om Lapparnas vrsprung [...] [Ed. by] K. B. Wiklund. Svenska Landsmål 17, 2. Uppsala.

Grönlund, J. U. 1848. Om Lapparne och deras gudar. Uppsala.

[Harva], U. 1915. Lappalaisten uskonto. [By] U. Holmberg. (Suomen suvun uskonnot 2). Porvoo.

Holsten, W. 1932. Christentum und nichtchristliche Religion nach der Auffassung Luthers. Gütersloh.

Hultkrantz, Å. 1962. Die Religion der Lappen. Die Religionen der Menschheit 3. Stuttgart.

Kildal, J. 1910. Ur Jens Kildals Appendix till hans verk "Afguderiets Dempelse". Källskrifter till lapparnas mytologi. [Ed. by] $\mathrm{E}$. Reuterskiöld. (Bidrag till vår odlings häfder 10.) Stockholm.

Krohn, K. 1906. Lappische Beiträge zur germanischen Mythologie. Finnischugrische Forschungen 6 . Helsinki.

Leem, K. 1767. Beskrivelse over Finmarkens Lapper [. . ] Kiøbenhavn.

Lehtisalo, T. 1924. Entwurf einer Mythologie der Jurak-Samojeden. (Mémoires de la Société Finno-Ougrienne 53.) Helsinki.

Lid, N. 1942. Gudar og gudedyrkning. Nordisk kultur 26. Stockholm.

Mebius, H. 1968. Värrō. (Skrifter utg. av Religionshistoriska institutionen i Uppsala, Hum. fak., 5.) Uppsala.

Nesheim, A. 1967. Eastern and Western elements in Lapp culture. (Instituttet for sammenlignende kulturforskning A, 26.) Oslo.

Nilsson, M. P. 1916. Om lappsk religion. Kristendomen och vår tid 11. Lund.

Nordland, O. 1969. Valhall and Helgafell. Syncretism. Ed. by S. S. Hartman. (Scripta Instituti Donneriani Aboensis 3.) Stockholm.

Olrik, A. 1905. Nordisk og lappisk Gudsdyrkelse. Danske studier 1905. København.

Olsen, I. 1910. Om Lappernes Vildfarelser og Overtro. Kildeskrifter til den Lappiske Mythologi 2. [Ed. by] J. Qvigstad. (Det Kgl. Videnskabers Selskabs Skrifter 1910, 4.) Trondhjem.

Pettersson, O. 1957. Jabmek and Jabmeaimo. (Lunds universitets årsskrift N.F. 1, $52,6$.$) Lund.$

- 1983. The god Ruto. Arv 39.

Rheen, S. 1897. En kortt Relation om Lapparnes Lefwarne och Sedher [...] [Ed. by] K. B. Wiklund. Svenska Landsmål 17, 1.

Rosén, H. 1919. Om lapparnas dödsrikesföreställningar. Fataburen.

Ränk, G. 1981. Der mystische Ruto in der samischen Mythologie. (Stockholm Studies in Comparative Religion 21.) Stockholm.

Sidenius, L. 1910. Relation. Kälskrifter till lapparnas mytologi. [Ed. by] E. Reuterskiöld. (Bidrag till vår odlings häfder 10.) Stockholm. 
Skanke, H. 1910. Ur Hans Skankes "Epitomes Historiae Missionis Lapponicae" 4. Recension af alle Lappiske ord og Terminus, som i Missions-Historien ere anförte [...] Källskrifter till lapparnas mytologi. [Ed. by] E. Reuterskiöld. (Bidrag till vår odlings häfder 10.) Stockholm.

Unwerth, W. v. 1911. Untersuchungen über Totenkult und Odinnverehrung bei Nordgermanen und Lappen mit Excursen zur altnordischen Literaturgeschichte. (Germanistische Abhandlungen 37.) Breslau.

Westen, T. v. 1910. Thomas von Westens bref till prästerskapet i Jämtland [...] den 11 mars 1723. Källskrifter till lapparnas mytologi. [Ed. by] E. Reuterskiöld. (Bidrag till văr odlings häfder 10.) Stockholm.

Vries, J. de 1956. Altgermanische Religionsgeschichte 1. Berlin.

Wiklund, K. B. 1916. Saivo. (Le monde oriental 10.) Uppsala. 